\title{
Cerita Rakyat Sebagai Bahan Pengayaan Literasi Budaya Bagi Pemelajar BIPA Tingkat Menengah
}

\author{
Dewi Prajnaparamitha Amandangi, Yeti Mulyati \& Yulianeta \\ Universitas Pendidikan Indonesia \\ E-mail: dewiamandangi@upi.edu; yetimulyati@upi.edu; yaneta@upi.edu
}

\begin{abstract}
How to cite (in APA Style): Amandangi, D.P., Mulyati, Y., \& Yulianeta. (2020). Cerita rakyat sebagai bahan pengayaan literasi budaya bagi pemelajar BIPA tingkat menengah. Jurnal Pendidikan Bahasa dan Sastra, Vol. 20(2), 157-165. doi: https://doi.org/10.17509/bs_jpbsp.v20i2.33056
\end{abstract}

Article History: (Received: 27 May 2020, Revised: 1 July 2020, Accepted: 15 Sept 2020)

Journal homepage: http://ejournal.upi.edu./index.php/BS_JPBSP

\begin{abstract}
Abstrak: Penyusunan bahan pengayaan cerita rakyat berguna untuk meningkatkan kemampuan literasi serta membentuk pengalaman apresiasi sastra bagi pemelajar BIPA. Namun, untuk merancang bahan pengayaan yang sesuai, perlu diadakan kegiatan pendahuluan untuk menganalisis kebutuhan agar bahan pengayaan yang dirancang dapat diterima dengan baik oleh pengguna di lapangan. Penelitian ini menggunakan metode kualitatif deskriptif. Eksplorasi kebutuhan bahan pengayaan teks cerita rakyat diperoleh melalui wawancara kepada tiga pengajar BIPA tingkat menengah, angket kebutuhan untuk pemelajar BIPA, dan analisis dokumen bahan pengayaan cerita rakyat pada laman BIPA daring Kemendikbud. Hasilnya, seluruh pengajar memerlukan adanya penyusunan bahan pengayaan cerita rakyat untuk meningkatkan kemampuan apresiasi sastra dan literasi budaya bagi pemelajar BIPA tingkat menengah. Selanjutnya, penyesuaian konten dan bentuk penyajian perlu dilakukan sebagai inovasi pada bahan pengayaan cerita rakyat bagi pemelajar BIPA berupa muatan, atau pengetahuan yang memiliki nilai kearifan lokal, nilai pariwisata, nilai sosial dan lain sebagainya.
\end{abstract}

Kata Kuci: Analisis kebutuhan; cerita rakyat; bahan pengayaan; BIPA; tingkat menengah

\section{Folklore as a teaching material for cultural literacy enrichment for Intermediate Level BIPA Students}

\begin{abstract}
The preparation of folklore enrichment materials is useful for improving literacy skills and forming literary appreciation experiences for BIPA students. However, in order to design suitable enrichment materials, preliminary activities are needed to analyze the needs so that the enrichment materials designed can be well received by users in the field. This research is a needs analysis using descriptive qualitative methods. Exploration of the need for folklore text enrichment materials was obtained through interviews with three intermediate-level BIPA teachers, a needs questionnaire for BIPA students, and analysis of folk story enrichment material documents on the Ministry of Education and Culture's online BIPA page. As a result, all teachers need the preparation of folklore enrichment materials to improve literary appreciation and cultural literacy skills for intermediate-level BIPA students. Furthermore, adjustments of content and presentation forms need to be made as an innovation in folklore enrichment materials for BIPA students in the form of content, or knowledge that has local wisdom values, tourism values, social values and so on.
\end{abstract}

Keywords: Needs analysis; folklore; enrichment materials; BIPA; intermediate level 


\section{PENDAHULUAN}

Salah satu poin dalam dunia literasi baru adalah literasi sumber daya manusia yang dapat dipahami sebagai suatu kemampuan dalam berkomunikasi, kolaborasi, berpikir kritis, kreatif, dan inovatif. Dalam literasi manusia, seseorang diharuskan memiliki keterampilan kepemimpinan, kerjasama, kelincahan budaya, latar belakang/ kepribadian, dan kewirausahaan. Terkait dengan pemelajar bahasa sebagai sumber daya, pada akhirnya tujuan pembelajaran BIPA harus dapat menghasilkan orangorang yang mumpuni di bidangnya, paling tidak mampu berkomunikasi dengan baik dan benar menggunakan bahasa Indonesia, serta tidak gegar budaya (Anggaira, 2019).

Kelincahan budaya dalam paparan tersebut, bisa didapatkan oleh pemelajar BIPA melalui kegiatan literasi budaya yang dikembangkan dan digencarkan oleh Gerakan Literasi Nasional (GLN) Indonesia. Literasi budaya merupakan kemampuan dalam memahami dan bersikap terhadap kebudayaan Indonesia sebagai identitas bangsa. Literasi budaya menjadi hal yang penting untuk dikuasai di abad ke-21. Indonesia memiliki beragam suku bangsa, bahasa, kebiasaaan, adat istiadat, kepercayaan, dan lapisan sosial. Oleh karena itu, kemampuan untuk menerima dan beradaptasi, serta bersikap secara bijaksana atas keberagaman ini menjadi sesuatu yang mutlak (Kemendikbud, 2017,p.3). Bukan hanya masyarakat Indonesia yang memerlukan literasi literasi budaya, namun pemelajar BIPA juga perlu melakukan hal ini agar tidak mengalami gegar budaya yang bersifat negatif. Faizin (2018) menjelaskan bahwa gegar budaya merupakan gangguan ketika segala hal yang biasa dihadapi ketika di tempat asal menjadi sama sekali berbeda dengan hal-hal yang dihadapi di tempat yang baru dan asing.

Ruskhan (2007), Kusmiatun (2018), Saddhono dan Erwinsyah (2018) berpendapat bahwa pengajaran bahasa asing dalam hal ini bahasa Indonesia, sesungguhnya tidak dapat dipisahkan dengan perkembangan sosial budaya masyarakat Indonesia. Penyajian aspek sosial budaya menjadi penting. Bagaimanapun juga, pengajaran BIPA harus disertai pemberian informasi budaya masyarakat Indonesia untuk membentuk sebuah pengetahuan yang harus diketahui. Hal ini senada dengan pendapat Sinaga (2010) dalam Sunendar, Cahyani, dan Mulyadi (2014) yang menyatakan bahwa pembelajaran dengan mengedepankan pendidikan berbasis budaya (budaya folklor) perlu dikembangkan di sekolahsekolah, karena dinilai dapat memotivasi para pembelajar untuk belajar lebih aktif hingga memberikan nilai tambah dan positif baginya.

Setiap bangsa memiliki berbagai macam kebudayaan yang mencerminkan nilai-nilai luhur bangsanya. Bangsa Indonesia sebagai masyarakat multikultural juga memiliki kekayaan budaya yang sangat melimpah. Cerita rakyat merupakan salah satu di antara sekian banyak kekayaan budaya yang dimiliki oleh bangsa Indonesia. Cerita rakyat Indonesia hadir dari berbagai macam daerah sehingga memiliki jumlah yang sangat banyak dan karakeristik yang beragam. Cerita rakyat dari berbagai daerah ini memiliki kekhasan tersendiri sebagai representasi atau gambaran tentang masyarakat setempat di mana cerita rakyat itu dilahirkan (Syamsiah, 2018).

Berdasarkan laman BIPA daring kemendikbud(https://bipa.kemdikbud.go. id), saat ini terdapat 287 lembaga formal maupun informal dari 29 negara penyelenggara program BIPA. Sebanyak 62 lembaga merupakan lembaga di Indonesia yang tersebar di berbagai daerah. Perkembangan pembelajaran BIPA ini merupakan lahan yang potensial untuk dikembangkan. Pengajaran BIPA diharapkan mampu menjadi sebuah sarana yang tepat untuk mengenalkan Indonesia kepada negara-negara lain (Nuraeni, 2016). Dengan demikian, bukan hanya bahan ajar, ketersediaan bahan pengayaan juga perlu 
diperhatikan untuk mendukung upaya internasionalisasi bahasa Indonesia.

Buku pengayaan adalah buku yang memuat materi yang dapat memperkaya buku teks pada jenjang pendidikan formal (Puskurbuk, 2018,p.5). Buku pengayaan memiliki fungsi untuk meningkatkan kemampuan berpikir peserta didik, serta memperluas wawasan mereka terhadap lingkungan berdasarkan pengetahuan terkini. Selain muatan substansi yang baik, buku pengayaan juga harus disajikan secara menyenangkan agar dapat menumbuhkan minat baca peserta didik. Secara spesifik, buku pengayaan dapat meningkatkan wawasan pengetahuan, keterampilan, dan kepribadian bagi peserta didik. Cerita rakyat sebagai bahan pengayaan, telah dikembangkan oleh Kementrian Pendidikan dan Kebudayaan (Kemendikbud) Republik Indonesia melalui laman BIPA daring. Setidaknya ada 25 bahan pengayaan cerita rakyat dari provinsi-provinsi yang ada di Indonesia. Menurut hemat penulis, dari sekian bahan pengayaan cerita rakyat tersebut, belum ada cerita rakyat yang berasal dari daerah Jawa Tengah. Oleh karena itu, Penulis bermaksud untuk melakukan sebuah penyusunan bahan pengayaan cerita rakyat dari daerah Jawa Tengah yang ditujukan sebagai bahan literasi budaya bagi pemelajar BIPA.

Penelitian ini merupakan sebuah analisis kebutuhan yang mengadopsi tahap pertama dari penelitian pengembangan 4$\mathrm{D}$ (define, design, develop, disseminate) yaitu pada tahapan define. Thiagarajana, Semmel, dan Semmel (1974,p.6) menyatakan bahwa tujuan dari tahapan ini adalah untuk menemukan dan menetapkan persyaratan pengajaran yang dibutuhkan. Tahap awal adalah kegiatan analisis, kemudian ditentukan tujuan dan kendala atas sebuah bahan pengayaan cerita rakyat yang akan dikembangkan.

\section{METODE}

Desain penelitian ini menggunakan kualitatif deskriptif. Hal ini didasarkan pada 1) data penelitian yang berupa hasil wawancara, hasil pengisian kuesioner dan hasil studi dokumen, 2) penelitian dilakukan secara alami, dan 3) peneliti berperan sebagai instrumen utama. Kegiatan wawancara dilakukan kepada kepada tiga dosen BIPA tingkat menengah di daerah Jawa, pengisian kuesioner dilakukan oleh pemelajar BIPA tingkat menengah secara random, dan dokumen yang dianalisis berupa buku cerita rakyat daring sebagai bahan pengayaan yang terdapat pada laman BIPA daring Kemendikbud.

Pedoman wawancara digunakan sebagai instrumen dalam wawancara semi terstruktur untuk mendapatkan data kebutuhan pengajar BIPA. Peneliti menyiapkan berkas wawancara dan melakukan wawancara secara alami. Data yang telah diperoleh kemudian dianalisis secara deskriptif untuk mendapatkan data sesuai dengan kebutuhan penelitian. Selain itu, instrumen berupa angket yang disusun menggunakan teknologi google form disebar kepada pemelajar BIPA secara random. Terdapat empat pemelajar BIPA yang dipilih sebagai data dalam penelitian ini karena empat mahasiswa tersebut sesuai dengan kriteria penelitian, yaitu pemelajar BIPA tingkat menengah.

Hasil penelitian diasosiasikan dalam kegiatan berikut. Pertama, menggali teori yang berkaitan dengan cerita rakyat sebagai bahan literasi budaya. Kedua menganalisis permasalahan yang dihadapi oleh pengajar BIPA sebagai objek. Ketiga, menganalisis cerita rakyat pada bahan ajar yang sudah tersedia. Keempat, menganalisis buku cerita rakyat pada laman BIPA daring Kemendikbud, dan Kelima, membuat spesifikasi cerita rakyat yang tepat sebagai bahan literasi budaya. Tahapan ini merupakan hal-hal yang terdapat dalam langkah define dalam penelitian pengembangan 4-D Thiagarajan, Semmel dan Semmel (1974). 


\section{HASIL DAN PEMBAHASAN}

\section{Cerita Rakyat Sebagai Bahan Literasi Budaya}

Cerita rakyat adalah bentuk penuturan cerita yang pada dasarnya tersebar secara lisan dan diwariskan secara turun temurun di kalangan penduduk secara tradisional (Depdikbud, 1982,p.1). Cerita rakyat dimungkinkan memiliki beberapa versi yang berbeda karena penyebarannya tidak tertulis. Jenis-jenis cerita rakyat (Depdikbud, 1982,p.1-2) meliputi mite, legenda, dan dongeng. Mite merupakan cerita yang dianggap benar-benar terjadi di masa lampau dan dinilai sakral oleh pemilik ceritanya. Mite memliki tokoh dewa atau setengah dewa. Legenda adalah cerita yang hampir mirip dengan mite, namun tidak benar-benar terjadi. Legenda memiliki tokoh manusia biasa yang memiliki kemampuan luar biasa. Sedangkan dongeng adalah cerita yang dianggap tidak benar-benar terjadi dan terjadinya dongeng tidak terikat waktu maupun tempat.

Cerita rakyat merupakan satu dari sekian banyak contoh kebudayaan yang dimiliki oleh Indonesia. Teks-teks cerita rakyat yang dibukukan atau dipublikasikan dalam bentuk digital merupakan sebuah sarana yang tepat untuk dijadikan sebagai bahan pembelajaran BIPA. Bukan hanya sebagai muatan materi dalam pembelajaran di kelas, teks cerita rakyat juga dinilai tepat jika digunakan sebagai bahan literasi budaya bagi pemelajar BIPA.

Kemendikbud

menjelaskan dalam salah satu poin ragam sumber belajar yang dapat digunakan oleh para pemelajar adalah pengayaan budaya melalui bahan cerita lokal dan nasional. Pemelajar perlu diperkenalkan bacaan lokal dan nasional. Bacaan lokal penting agar siswa mengetahui karya sastra daerah yang dilahirkan nenek moyang dan juga para penulis yang hidup pada masa kini. Penting bagi pemelajar untuk mengetahui nilai dan pesan yang bersumber dari daerah di mana cerita itu berasal. Sementara itu, bahan cerita nasional juga tidak kalah penting bagi pemelajar untuk mengenali keanekaragaman kisah dari berbagai penjuru tanah air. Cerita nasional dapat bersumber dari cerita daerah dari daerah lain atau cerita terkini (sastra modern) yang dihasilkan oleh sastrawan Indonesia.

\section{Analisis Kebutuhan Pengajar BIPA}

Teks cerita rakyat merupakan materi ajar yang diberikan sesuai dengan silabus, yaitu pada jenjang BIPA 4 atau jenjang menengah. Materi ini disesuaikan dengan elemen kompetensi dan indikator lulusan, tepatnya pada unit membaca. Pembelajar diharapkan mampu mengidentifikasi kalimat atau kumpulan kalimat yang mengandung pesan moral dalam dongeng atau cerita rakyat, serta mampu membandingkan dongeng dan cerita rakyat yang serupa di Indonesia dengan di negaranya (Permendikbud RI No. 27 Th 2012). Kegiatan ini diklasifikasikan dalam kegiatan apresiasi dan kreasi sastra. Menurut para pengajar, pemelajar BIPA terlihat antusias ketika mengikuti pembelajaran dengan materi cerita rakyat. Apalagi ketika teks yang digunakan memadahi dan pemelajar dilibatkan dalam kegiatan kreasi sastra. Jadi, pemelajar tidak hanya membaca atau mendengarkan pembacaan teks cerita rakyat tetapi juga melakukan kreasi seperti menghadirkan drama dari teks tersebut.

Kendala yang ditemukan oleh pengajar BIPA dalam pembelajaran apresiasi adalah berasal dari dalam teks yang ada di dalam bahan ajar atau bahan pengayaan. Sebagian teks cerita rakyat memiliki kata atau kalimat sastrawi yang sulit dipahami oleh sebagian pemelajar. Biasanya pengajar menggunakan bahan ajar yang disediakan oleh PPSDK dan menggunakan bahan pengayaan berupa teks bermuatan kearifan lokal. Sebagai bahan pengayaan, para pengajar biasanya menemukan teks cerita rakyat dengan berselancar pada laman daring. Meskipun Kemendikbud sudah menyediakan bahan pengayaan cerita rakyat secara daring, tetapi para pengajar masih belum menggunakan bahan pengayaan ini secara maksimal. Hal ini dikarenakan cerita rakyat 
yang disediakan oleh Kemendikbud merupakan cerita rakyat yang bersifat kedaerahan atau tidak populer. Ceritacerita dari berbagai daerah ini mengangkat kearifan lokal, tetapi masih belum dikenal dengan baik oleh pengajar BIPA. Padahal, para pengajar membutuhkan cerita rakyat yang sudah dikenal luas oleh masyarakat Indonesia. Cerita rakyat yang popular dinilai dapat memudahkan pemelajar BIPA dalam proses pembelajaran. Mereka juga dapat dengan mudah mengkonfirmasi cerita rakyat popular kepada masyarakat Indonesia asli. Harapannya, para pemelajar dapat memperoleh informasi tambahan untuk meningkatkan kompleksitas pengetahuan cerita rakyat yang dipelajarinya.

Sesuai dengan pendapat pengajar, perlu adanya penyususnan bahan pengayaan cerita rakyat yang disesuaikan dengan tujuan yang diharapkan. Misalnya adalah, menambahkan beberapa nilai yang diintegrasikan dalam teks cerita rakyat. Contohnya adalah nilai budaya, nilai kearifan lokal, nilai sastra lingkungan, dan juga nilai-nilai yang lain. Menurut salah seorang pengajar, nilai pengetahuan pariwisata juga dapat disertakan dalam teks cerita rakyat berupa legenda. Hal ini tentu saja sejalan dengan misi pengajaran BIPA yaitu sebagai duta kebudayaan dan pariwisata. Pengajar BIPA hendaknya menyebarluaskan pengetahuan tentang kepariwisataan yang ada di Indonesia. Harapannya, pemelajar tidak hanya tertarik untuk mempelajari teks cerita rakyat, tetapi juga tertarik untuk mengunjungi tempattempat pariwisata yang tercantum dalam teks cerita rakyat tersebut.

Bentuk bahan pengayaan yang diharapkan oleh para pengajar berupa teks cetak yang berbentuk buku atau antologi cerita rakyat. Hal ini dapat memudakahkan pemelajar dalam proses membaca dan memudahkan penulis untuk melakukan perbaikan jika ada revisi pada proses penelitian. Selain itu, penyusunan buku dapat diajukan ke Puskurbuk untuk mendapatkan HAKI. Di sisi lain, pengajar tidak membatasi jika penulis berkehendak untuk membuat bahan pengayaan secara daring yaitu melalui web atau blog dengan kelebihan berupa cerita rakyat dapat diakses oleh pemelajar BIPA di seluruh penjuru dunia, tetapi pembuatan web yang berbayar juga harus dipertimbangkan.

\section{Analisis Kebutuhan Pemelajar BIPA}

Berdasarkan data, pemelajar BIPA yang mengisi kuseioner kebutuhan adalah sebagai berikut. 1) R pemelajar di Unpad yang berasal dari Tiongkok, 2) F pemelajar Guangxi University for Nationalites, Tiongkok, 3) Y pemelajar di Balai Bahasa UPI berasal dari Jepang, 4) N pemelajar di Balai Bahasa UPI berasal dari Thailand, Berdasarkan pengisian kuesioenr, didapatkan data tentang ketertarikan terhadap materi teks cerita rakyat $\mathrm{Hal}$ ini dicantumkan pada gambar grafik berikut.

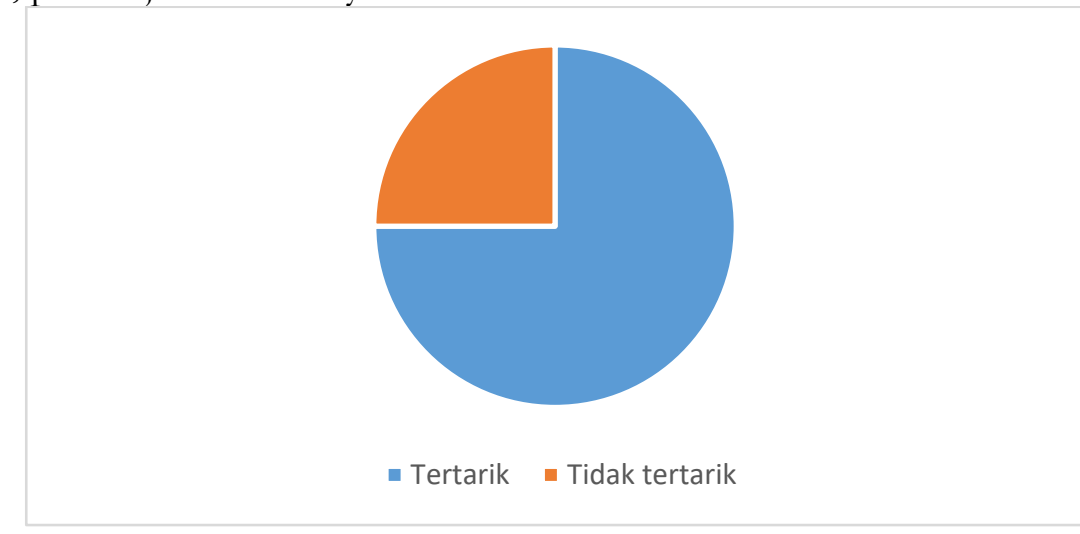

Grafik 1. Ketertarikan Pemelajar terhadap Materi Teks Cerita Rakyat 
Sebesar 75\% dari pemelajar BIPA mengaku tertarik dengan materi teks cerita rakyat, dan berkeinginan untuk mempelajari teks cerita rakyat dengan lebih mendalam. Sementara 25\% yang lain tidak tertarik dengan materi teks cerita rakyat tetapi tetap mempelajari teks cerita rakyat secara formal karena terdapat pada silabus pembelajaran. Sebagia besar pemelajar menggunakan bahan belajar berupa buku paket, buku kumpulan teks cerita rakyat, serta teks cerita rakyat yang terdapat di internet. Berdasarkan data yang terdapat pada lembar kuesioner didapatkan bahwa pemelajar BIPA tingkat menengah ini juga mengaku membutuhkan bahan belajar yang disusun dengan memiliki muatan-muatan tertentu untuk mempermudah proses belajar mandiri. Dalam kuesioner, Peneliti menawarkan ketertarikan pemelajar BIPA terhadap muatan budaya dan pariwisata untuk disertakan dalam bahan ajar BIPA dengan hasil sebagai berikut.

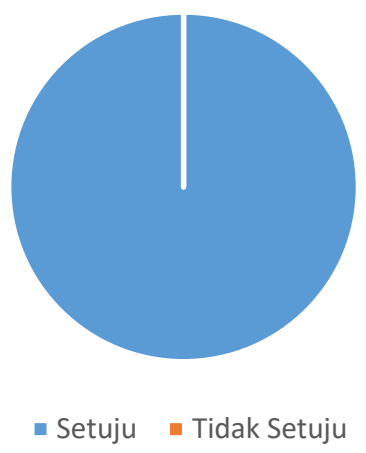

Grafik 2. Ketertarikan Pemelajar terhadap Muatan Budaya Dan Pariwisata

Seluruh responsden mengaku setuju jika terdapat sebuah bahan ajar teks cerita rakyat yang memiliki muatan budaya dan pariwisata Indonesia. Hal ini dinilai sebagai muatan autentik yang dapat dipelajari oleh pemelajar dalam mempelajari sebuah materi. Tidak hanya melalui satu sudut pandang, tetapi melalui tiga sudut pandang sekaligus. Hal ini tentu saja menjadi sesuatu yang menarik dan memiliki kebaruan produk. Hal ini juga yang dapat menjadikan bahan pengayaan teks cerita rakyat berbasis web memiliki suatu kelebihan atau daya tarik tersendiri bagi pengguna di kemudian hari.

\section{Kondisi Cerita Rakyat pada Bahan Ajar BIPA Menengah}

Bahan ajar Sababatku Indonesia merupakan bahan ajar yang digunakan oleh lembaga BIPA pada umumnya. Bahan ajar ini disusun oleh Pusat Pengembangan
Strategi dan Diplomasi Kebahasaan, Badan Pengembangan dan Pembinaan Bahasa, Kementerian Pendidikan dan Kebudayaan Republik Indonesia. Pada bahan ajar tingkat B1, Bab Cerita Sebelum Tidur, terdapat dua teks cerita rakyat yang disajikan secara tertulis, yaitu Kancil dan Buaya serta Tangkuban Perahu dalam bentuk dialog. Sedangkan dalam bahan simakan, terdapat pengetahuan tentang cerita rakyat Malin Kundang, Bawang Merah dan Bawang Putih, serta Timun Mas. Pada bagian simakan, teks yang disajikan adalah sebatas pemberian informasi. Bukan teks cerita rakyat secara utuh. Pada akhir Bab, muatan budaya yang disajikan adalah pengetahuan tentang Tari Piring. Selanjutnya, pada bahan ajar tingkat B2, terdapat dua teks tertulis dan satu buat teks simakan tentang cerita rakyat Indonesia. Malin Kundang dan Riwayat Si Batu adalah teks tertulis, sedangkan Timun Mas berupa teks simakan. Pada akhir Bab, pengetahuan 
tentang budaya merantau disertakan sebagai bahan literasi bagi pemelajar BIPA.

Berdasarkan data tersebut, dapat diketahui bahwa jumlah cerita rakyat yang terdapat di dalam bahan ajar BIPA tingkat menengah masih sangat terbatas jumlahnya. Informasi-informasi yang terkandung di dalam teks cerita pendek juga belum diulas secara menyeluruh. Informasi budaya yang terdapat dalam catatan budaya juga masih terbatas jumlahnya. Padahal, jika dikaji lebih lanjut, teks cerita rakyat Indonesia memiliki jumlah yang sangat banyak. Nilai-nilai yang terkandung dalam teks cerita rakyat juga beragam, seperti nilai kearifan lokal, nilai pariwisata, nilai sosial, dan lain sebagainya. Peneliti berpendapat bahwasannya berbagai macam nilai ini dapat dikembangkan sebagai bahan literasi budaya bagi pemelajar BIPA.

\section{Kondisi Cerita Rakyat pada Laman BIPA Daring}

Bahan pengayaan cerita rakyat berupa buku elektronik dalam laman BIPA daring Kemendikbud berjumlah 25 buku. Cerita rakyat tersebut merupakan cerita rakyat kedaerahan yang berasal dari provinsi-provinsi yang ada di Indonesia. Setidaknya ada sebelas cerita rakyat dari pulau Sumatra, empat cerita rakyat dari pulau Jawa, dua cerita rakyat dari Bali, lima cerita rakyat dari pulau Kalimantan, satu dari pulau Papua, dan satu yang lain tidak dicantumkan daerah asal cerita rakyat itu berkembang. Berdasarkan klasifikasi tersebut, penulis menemukan bahwasanya empat cerita rakyat di pulau jawa terdiri atas cerita rakyat dari DKI Jakarta, Jawa Barat, Daerah Istimewa Yogjakarta, dan Jawa Timur. Artinya, belum ada buku cerita rakyat dari daerah Jawa Tengah.

Cerita rakyat dalam laman BIPA daring ini merupakan bacaan setingkat SMP yang dikembangkan oleh Kemendikbud sebagai bahan pengayaan literasi. Sifat cerita rakyat yang kedaerahan ini memiliki segi posisitif yaitu sebagai bentuk pelestarian kebudayaan setempat yang mungkin hampir punah, serta ditujukan untuk mengangkat kearifan lokal yang ada di sebuah daerah. Kekurangannya, cerita rakyat ini belum dikenal dengan baik oleh masyarakat Indonesia sehingga dimungkinkan terjadi hambatan pemahaman jika pemelajar BIPA berusaha untuk mengkonfirmasikan cerita kepada masyarakat luas.

Dari segi penyajian, bahan pengayaan cerita rakyat telah disusun secara runtut, bersistem, dan lugas. Cerita rakyat yang tercantum dalam bahan pengayaan merupakan cerita rakyat yang relatif panjang, kemudian dibagi dalam beberapa subjudul. Bahan pengayaan ini tidak seperti antologi yang memiliki berbagai macam cerita. Secara singkat, struktur cerita rakyat ini mudah dipahami oleh pembaca. Penyajian materi juga dilakukan dengan familiar dan menyenangkan. Buku daring ini memiliki rata-rata jumlah halaman sebanyak 60 sampai dengan 80 halaman, dengan ilustrasi gambar sebagai pelengkapnya.

Bahasa yang etis, estetis, dan komunikatif dinilai sudah disesuaikan dengan tingkat pemahaman pembaca sasaran. Bahasa yang digunakan juga fungsional dan kontekstual, tetapi peneliti menemukan beberapa buku yang memiliki organisasi bahasa yang kurang efektif dan efisien. Bahasa yang digunakan dalam cerita rakyat pada laman BIPA daring adalah Bahasa Indonesia dan bahasa Inggris (dwibahasa). Pada sebagian buku, penulis menggunakan teks Bahasa Indonesia untuk menceritakan satu subbab cerita, diikuti ilustrasi gambar, kemudian teks dalam bahasa Inggris. Di sebagian buku yang lain, cerita terkesan terpecah. Cerita ini menggunakan dua paragraf berbahasa Indonesia, kemudian diubah menjadi bahasa Inggris, kemudian ada juga ilustrasi gambar. Struktur bahasa yang seperti ini dinilai kurang tepat karena menyebabkan kurangnya fokus ketika membaca teks cerita rakyat.

Unsur grafika dinilai telah etis, dinamis dan menarik. Ilustrasi gambar dapat mendukung pemahaman pemelajar terhadap isi teks cerita rakyat secara umum, 
tetapi kurang mendukung dalam hal literasi budaya. Ilustrasi gambar sudah memadai, tetapi seharusnya mampu memberikan penguatan dalam proses pemahaman unsur budaya yang ada di dalam teks. Misalnya, ilustrasi tempat sebagai setting cerita atau pakaian yang dikenakan tokoh dapat digambarkan dengan lebih detail, sehingga pembaca mampu menangkap muatan kearifan lokal yang terdapat dalam cerita rakyat bukan hanya melalui teks, namun juga melalui ilustrasi yang menyertainya.

\section{Pengembangan Bahan Pengayaan Berdasarkan Analisis Kebutuhan}

Hasil analisis ini akan dijadikan sebagai catatan penting bagi peneliti sebagai bahan acuan untuk menyusun sebuah bahan pengembangan cerita rakyat. Kesesuaian antara cerita rakyat dengan kegiatan literasi budaya menjadi pertimbangan yang kuat sebagai dasar penyusunan bahan pengayaan. Cerita rakyat dari daerah Jawa Tengah dinilai memiliki potensi yang memungkinkan untuk dikembangkan sebagai bahan pengayaan literasi bagi pemelajar BIPA. Pemilihan cerita rakyat daerah Jawa Tengah ini juga didasari oleh jumlah lembaga penyelenggara BIPA dan jumlah pemelajar yang relatif banyak.

Cerita rakyat yang dimuat dalam bahan pengayaan dapat berupa cerita rakyat populer atau cerita rakyat yang sudah dikenal dengan baik oleh masyarakat Indonesia. Sebagai bentuk variasi dari bahan pengayaan yang terdapat dalam laman BIPA daring Kemendikbud, bentuk antologi atau kumpulan dari beberapa cerita rakyat dapat dipilih sebagai sebuah inovasi. Ilustrasi gambar yang mendukung kegiatan literasi budaya sangat dibutuhkan dalam pengembangan bahan pengayaan cerita rakyat. Bukan hanya teks yang memiliki muatan budaya, namun ilustrasi yang digunakan juga harus memiliki muatan budaya Indonesia.

Di samping itu, berbagai muatan perlu diintegrasikan maupun ditambahkan di dalam teks cerita rakyat. Muatan tersebut dapat berupa nilai-nilai kearifan lokal, nilai pariwisata, nilai sosial dan lain sebagainya. Muatan ini diharapkan mampu mendukung proses konstruksi pengetahuan kebudayaan pada pemelajar BIPA. Proses literasi budaya melalui teks cerita rakyat diharapkan mampu meningkatkan pengalaman pemelajar BIPA dalam kegiatan apresiasi maupun kreasi sastra. Bahan pengayaan ini juga diharapkan dapat mencegah pemelajar BIPA mengalami berbagai gegar budaya yang berlebihan ketika berinteraksi langsung dengan masyarakat Indonesia sebagai penutur asli, maupun ketika pemelajar BIPA berada di Indonesia saat proses belajar.

\section{SIMPULAN}

Berdasarkan temuan dan hasil analisis kebutuhan serta pembahasan maka dapat disimpulkan bahwa dibutuhkan sebuah pengembangan bahan pengayaan teks cerita rakyat daerah Jawa Tengah yang diharapkan dapatdigunakan dalam kegiatan literasi budaya bagi pemelajar BIPA. Muatan nilai-nilai kearifan lokal, pariwisata, sastra lingkungan, dan lain sebagainya dapat diintegrasikan maupun ditambahkan dalam bentuk paparan sebagai sarana untuk meningkatkan pengetahuan budaya. Bentuk antologi atau kumpulan cerita rakyat diharapkan mampu menjadi inovasi dalam bentuk bahan pengayaan cerita rakyat pada laman BIPA daring Kemendikbud. Ilustrasi bermuatan kebudayaan juga dinilai tepat untuk mendukung kegiatan literasi budaya untuk meminimalisir gegar budaya pemelajar BIPA.

Penelitian ini merupakan studi pendahuluan untuk proses penelitian yang selanjutnya. Oleh karena itu, penilitian ini masih harus dilanjutkan dengan penyusunan teks cerita rakyat populer di daerah Jawa Tengah dengan mempertimbangkan berbagai muatan nilai. Setelah prototipe bahan pengayaan cerita rakyat telah selesai dikembangkan, terdapat tahapan penilaian pakar, kemudian disebarluaskan sebagai bahan pengayaaan untuk mendukung literasi budaya bagi pemelajar BIPA. 


\section{DAFTAR RUJUKAN}

Anggaira, A.S. (2019). Literasi Terkini dalam Pembelajaran BIPA pada Era Revolusi Digital. Prosiding Seminar Nasional Pendidikan Program pascasarjana Universitas PGRI Palembang 12 januari 2019.

Depdikbud. (1982). Ceritera Rakyat Daerah Jawa Tengah. Jakarta: Departemen Pendidikan dan Kebudayaan.

Faizin. (2018). Literasi Budaya Lokal untuk Meminimalisis Gegar Budaya Pemelajar BIPA. Prosiding SENABASA (Seminar Nasional Babasa dan Sastra) Edisi 3, 116-124. Retrieved from: http://researchreport.umm.ac.id/index.php

Kemendikbud. (2017). Materi Pendukung Literasi Budaya dan Kewargaan. Jakarta: Kementrian Pendidikan dan Kebudayaan.

Kusmiatun, A. (2018). Cerita Rakyat Indonesia Sebagai Materi Pembelajaran BIPA: Mengusung Masa Lalu Untuk Pembelajaran BIPA Masa Depan. Diksi, 26(1), 2428.

Puskurbuk. (2018). Panduan Pemiliban Buku Nonteks Pelajaran/Pusat Kurikulum dan Perbukuan. Jakarta: Pusat Kurikulum dan Perbukuan.

Ruskhan, A. G. (2007). Pemanfaatan Keberagaman Budaya Indonesia dalam Pengajaran Bahasa Indonesia Bagi Penutur Asing (BIPA).
Makalah. Disajikan dalam Seminar Pengajaran Bahasa Indonesia Pertemuan Asosiasi JepangIndonesia di Nanzan Gakuen Training Center, Nagoya, Jepang, 10-11 November 2007.

Thiagarajan, S., Semmel, D. S. \& Semmel, M.I. (1974). Instructional Dvelopment for Training Teachers of Exeptional Children: A Sourcebook. Leadership Training Institute/Special Education, University of Minnesota.

Saddhono, K., \& Husein, E. (2018). Foklore as Local Wisdom for Teaching Materials in BIPA Program (Indonesian for Foreign Speakers). In International Conference on Social and Political Issues (the 1st ICSPI, 2016) "Knowledge and Social Transformation", KnE Social Sciences, p. 444-454.

Sunendar, D., Cahyani, D., \& Mulyadi, Y. (2014). Implementasi metode ecriture créative berbasis budaya lokal untuk meningkatkan keterampilan menulis Bahasa Perancis Level B1 DELF. Jurnal Pendidikan Bahasa dan Sastra, 14(2), 230-241.

DOI: https://doi.org/10.17509/bs _jpbsp.v14i2.721

Syamsiah. (2018). Kearifan Lokal yang Tercermin dalam Cerita Rakyat Masyarakat Melayu Kapuas Hulu. Artikel Penelitian. Pontianak: Universitas Tanjungpura. 
Amandangi, Mulyati \& Yulianeta, Cerita rakyat sebagai bahan pengayaan literasi budaya ... 